\title{
Erratum to: Radiocarbon calibration: The next generation
}

\author{
Richard A STAFF ${ }^{*}$ \& Ruiliang LIU ${ }^{2 \dagger}$ \\ ${ }^{1}$ Scottish Universities Environmental Research Centre (SUERC), University of Glasgow, East Kilbride G75 OQF, UK; \\ ${ }^{2}$ School of Archaeology, University of Oxford, Oxford OX1 3TG, UK
}

Erratum to: Sci China Earth Sci, 2021, 64: 507-510, https://doi.org/10.1007/s11430-020-9722-x

Citation: Staff R A, Liu R. 2021. Erratum to: Radiocarbon calibration: The next generation. Science China Earth Sciences, 64(5): 838, https://doi.org/10.1007/ s11430-021-9769-2

The article Radiocarbon calibration: The next generation, written by Richard A STAFF and Ruiliang LIU, was originally published in Vol. 64 Issue 3 without open access. With the author(s)' decision to opt for Open Choice the copyright of the article changed in April 2021 to (C) The Author(s) 2021 and the article is forthwith distributed under the terms of the Creative Commons Attribution 4.0 International License (http://creativecommons.org/licenses/by/4.0/), which permits use, duplication, adaptation, distribution and reproduction in any medium or format, as long as you give appropriate credit to the original author(s) and the source, provide a link to the Creative Commons license and indicate if changes were made.

The original article has been corrected.

Open Access This article is licensed under a Creative Commons Attribution 4.0 International License (https://creativecommons.org/licenses/by/4.0/), which permits use, sharing, adaptation, distribution and reproduction in any medium or format, as long as you give appropriate credit to the original author(s) and the source, provide a link to the Creative Commons licence, and indicate if changes were made. The images or other third party material in this article are included in the article's Creative Commons licence, unless indicated otherwise in a credit line to the material. If material is not included in the article's Creative Commons licence and your intended use is not permitted by statutory regulation or exceeds the permitted use, you will need to obtain permission directly from the copyright holder. To view a copy of this licence, visit http://creativecommons.org/licenses/by/4.0/.

The online version of the original article can be found at https://doi.org/10.1007/s11430-020-9722-x. 